\title{
Internal Neurolysis (Nerve Combing) for Trigeminal Neuralgia without Neurovascular Compression
}

\section{Neurólise interna (nerve combing) para neuralgia do trigêmeo sem compressão neurovascular}

\author{
Marco Gonzales-Portillo ${ }^{1}$ Luis Adrián Huamán ${ }^{2}$ \\ ${ }^{1}$ Instituto Neurociencias de Lima, Universidad Peruana Cayetano \\ Heredia, Lima, Perú \\ 2 Servicio de Neurocirugía, Hospital Nacional Dos de Mayo, Lima, Perú \\ Arq Bras Neurocir 2021;40(1):59-70.
}

Address for correspondence Marco Gonzales-Portillo, MD, Instituto Neurociencias de Lima, Del Pinar 198, Surco. 15038, Lima, Perú (e-mail: marcogps@outlook.com).

\begin{abstract}
Keywords

- internal neurolysis

- nerve combing

- trigeminal neuralgia

- root entry zone

- neurovascular compression

- microvascular decompression

Resumo

Objective The aim of the present study was to describe and evaluate the initial and the long-term clinical outcome of internal neurolysis (IN) for trigeminal neuralgia (TN) without neurovascular compression (NVC).

Methods A total of 170 patients diagnosed with TN were treated by posterior fossa exploration, during the period between April 2012 and October 2019. The patients were divided into two groups: Group A ( 50 patients) was treated by IN and Group B ( 120 patients) received microvascular decompression (MVD). Surgical outcomes and postoperative complications were compared between the two groups. Pain intensity was assessed by the Barrow Neurological Institute (BNI) pain intensity score and BNI facial numbness score. Pain recurrence was statistically evaluated with Kaplan-Meier analysis. Results Pain was completely relieved in 44 patients (88\%) who underwent IN (group A); 3 (6\%) experienced occasional pain but did not require medication (BNI 2). In group B, 113 (94\%) experienced immediate pain relief after MVD. The median duration of follow-ups was 4 years ( 6 months to 7.5 years). In Group A, there was a meantime recurrence of 27 months in 3 patients (6\%). The recurrence in Group B was of 5.8\% during the follow-up period. There were no statistically significant differences in the surgical outcomes between the two groups. All patients with IN experienced some degree of numbness, $88 \%$ of the cases resolved in 6 months, on average.

Conclusion Internal neurolysis is an effective, safe and durable treatment option for trigeminal neuralgia when NVC is absent.

Objetivo O propósito do presente estudo foi descrever e avaliar o resultado clínico inicial e a longo prazo da neurólise interna (IN, na sigla em inglês) para neuralgia do trigêmeo (TN, na sigla em inglês) sem compressão neurovascular (NVC, na sigla em inglês).
\end{abstract}

received

August 1, 2020

accepted

September 25, 2020

published online

January 18, 2021
DOI https://doi.org/

10.1055/s-0040-1721334. ISSN 0103-5355.

\footnotetext{
(c) 2021. Sociedade Brasileira de Neurocirurgia. All rights reserved. This is an open access article published by Thieme under the terms of the Creative Commons Attribution-NonDerivative-NonCommercial-License, permitting copying and reproduction so long as the original work is given appropriate credit. Contents may not be used for commercial purposes, or adapted, remixed, transformed or built upon. (https://creativecommons.org/ licenses/by-nc-nd/4.0/)

Thieme Revinter Publicações Ltda., Rua do Matoso 170, Rio de Janeiro, RJ, CEP 20270-135, Brazil
} 


Palavras-chave
- neurólise interna
- nerve combing
- neuralgia do trigêmeo
- zona de entrada da
raiz
- compressão
neurovascular
- descompressão
microvascular

Métodos. Um total de 170 pacientes diagnosticados com TN foram tratados pela exploração da fossa posterior, durante o período entre abril de 2012 e outubro de 2019. Os pacientes foram divididos em dois grupos: o grupo A foi tratado com IN (50 pacientes) e o grupo B recebeu descompressão microvascular (DMV) (120 pacientes). Resultados cirúrgicos e complicações pós-operatórias foram comparados entre os dois grupos. A intensidade da dor foi avaliada pelo escore de intensidade de dor do Barrow Neurological Institute (BNI, na sigla em inglês) e pelo escore de dormência facial do BNI. A recorrência da dor foi avaliada estatisticamente com a análise de Kaplan-Meier. Resultados A dor foi completamente aliviada em 44 pacientes (88\%) submetidos a IN (grupo A); em 3 (6\%) houve dor ocasional, mas não necessitaram de medicação (BNI 2). No grupo B, 113 (94\%) experimentaram alívio imediato da dor após DMV. A duração média do acompanhamento foi de 4 anos (6 meses a 7,5 anos). No grupo $A$, houve recorrência em três pacientes (6\%). $O$ tempo médio de recorrência foi de 27 meses. $A$ recorrência no grupo $B$ foi de $5,8 \%$ nesse período de acompanhamento. Não houve diferenças estatisticamente significativas nos resultados cirúrgicos entre os dois grupos. Todos os pacientes com IN experimentaram algum grau de dormência, em 88\% dos casos, resolvidos em 6 meses, em média.

Conclusões A IN é uma opção de tratamento atraente, eficaz, segura e durável para a neuralgia do trigêmeo quando a NVC está ausente.

\section{Introduction}

Vascular arterial contacts with the dorsal root of the trigeminal nerve were first described in 1929, by Dandy. ${ }^{1}$ These findings were characterized in subsequent communications. ${ }^{2,3}$ In his 1934 publication, "Concerning the cause of trigeminal neuralgia," Dandy describes the total or subtotal division of the trigeminal root in 215 cases. $^{3}$ Through a lateral suboccipital craniectomy without the aid of illumination and magnification afforded by an operating microscope, Dandy was able to identify compression on the trigeminal nerve root by a superior cerebellar artery (SCA) loop, in 66 cases $(30.7 \%)$; compression by a branch of the superior petrosal vein in $30(14 \%)$, and a dolichoectatic basilar artery in $6(2.7 \%)$, for a total of 102 cases $(47 \%){ }^{3-5}$

Dandy postulated that the vascular compression of the trigeminal roots was a major cause of tic douloureux. ${ }^{3,6}$ However, vascular transposition was not used by Dandy to attempt to relieve the pain; rather, selective section of the trigeminal nerves was performed.

In 1959, Gardner et al. reported a series of 100 patients in whom an extradural subtemporal approach was used to manipulate and free up the sensory root of the trigeminal nerve from its dural sleeve. Exploration of the trigeminal nerve through the posterior fossa, without magnification, was performed in two patients with recurrence. In one patient, an arterial loop was found lying against the nerve at the pons. Pain was completely relieved by separating the vessel from the nerve with a piece of Gelfoam. The second patient was relieved of pain following removal of a large meningioma compressing the trigeminal nerve. It was concluded that the critical part of the operation appeared to be a neurolysis or manipulation of the sensory root of the trigeminal nerve at the point where it crosses the apex of the petrous bone. Gentle manipulation of the sensory root could be done through a middle or a posterior fossa approach. "The cause of trigeminal neuralgia, therefore, presumably lies in the sensory root."7

In 1962, Gardner published "Concerning the mechanism of trigeminal neuralgia and hemifacial spasm." He reported a series of suboccipital approaches that followed a failed middle fossa procedure in 18 cases for trigeminal neuralgia (TN) from 1955 to 1961. Although in the era that predated neurosurgical use of the operative microscope, he found an artery loop that compressed and encircled the nerve in 6 cases. $^{8}$ There was no mention of the treatment those 6 patients received. Rand reported in 1981 a personal communication with Gardner, where he was informed that the treatment of TN involved either removing the offending lesion such as a tumor, or performing a vascular decompression by dissecting the arterial compressing loop away from the trigeminal root, and placing Gelfoam in between at the level of the pons. ${ }^{9}$

Jannetta, in 1967, still a neurosurgical resident at the time, participated in a workshop titled "Structural Mechanisms of Trigeminal Neuralgia." ${ }^{10}$ Reporting five patients with TN, he operated using a binocular dissecting microscope following exposure of the nerve through the transtentorial subtemporal approach to the cerebellopontine angle. He found that the trigeminal nerve was mildly to severely distorted and compressed by one or more small tortuous arteries that appeared to be branches of the SCA. In four out of five patients, he was able to free the artery from the fine to dense arachnoidal membranes, allowing the vessel to assume a new position away from the nerve. He performed a partial to total section of the portio major in all cases. Jannetta hypothesized that it was possible that this minor arterial distortion of the trigeminal nerve at the pons may be a contributing factor in TN. "This possible definitive procedure, namely, release of the artery without nerve section, is planned in a future series of patients." 10 
Table 1 Incidence of neurovascular compression

\begin{tabular}{|l|l|l|l|}
\hline Authors & Patients & $\begin{array}{l}\text { With } \\
\text { Vascular } \\
\text { Conflict } \\
(\%)\end{array}$ & $\begin{array}{l}\text { No } \\
\text { vascular } \\
\text { Conflict } \\
(\%)\end{array}$ \\
\hline Van Loveren et al. ${ }^{17} 1982$ & 50 & 82 & 18 \\
\hline Piatt et al. $^{18} 1984$ & 103 & 76.7 & 23.3 \\
\hline Zorman et al. $^{19} 1984$ & 118 & 76.3 & 23.7 \\
\hline Benderson et al. $^{20} 1989$ & 243 & 87.7 & 12.3 \\
\hline Klun $^{21} 1992$ & 215 & 80.5 & 19.5 \\
\hline Baechli et al. $^{22} 2007$ & 40 & 87.5 & 12.5 \\
\hline Leal et al. $^{23} 2010$ & 100 & 91 & 9 \\
\hline Revuelta et al. ${ }^{24} 2013$ & 271 & 83.8 & 16.2 \\
\hline Ko et al. ${ }^{25} 2015$ & 156 & 82.7 & 17.3 \\
\hline Hitchon et al. ${ }^{26} 2019$ & 69 & 87 & 13 \\
\hline Yang et al. ${ }^{27} 2019$ & 298 & 88.6 & 11.4 \\
\hline
\end{tabular}

In a 1974 letter published in JAMA, Jannetta described his 8-year experience with 150 cases of tic douloureux. He reported having found compression-distortion of the nerves with resultant pain control after vascular decompression. ${ }^{11}$ The approach used was not described. This was followed by complete manuscripts published in 1976 and $1977 .^{12,13}$

Jannetta became the first neurosurgeon to explore the cranial nerves within the posterior fossa by using an operating microscope, modifying Dandýs original suboccipital approach and developing a set of microneurosurgical instruments. Therefore, the idea that TN was a neurovascular compression was revived, and the treatment of this problem by microvascular decompression (MVD) was developed.

In spite of some initial controversy, today MVD represents the best and the most widely used surgical treatment for TN, because it offers the best long-term cure rates and preserves facial sensation. ${ }^{14-16}$

Neurovascular compression (NVC) of the trigeminal nerve has been identified in most cases of TN; however, the absence of NVC in TN is also common and has been described in the literature in 9 to $23.7 \%$ of the cases (- Table 1). ${ }^{17-27}$ Many surgical modalities are appropriate for MVD candidates who exhibit no NVC on magnetic resonance imaging (MRI), such as percutaneous balloon compression, radiofrequency thermocoagulation, glicerol rhizolysis, and radiosurgical techniques.

In the case of negative microsurgical suboccipital retrosigmoid exploration of the trigeminal root, the intraoperative management options have not been established. Surgical strategies include internal neurolysis (IN), trigeminal root compression (TRC) and partial sensory rhizotomy (PSR).

Internal neurolysis, also referred to as "nerve combing" or "neurocombing", is a procedure in which all or portions of the trigeminal nerve are divided longitudinally along its fibers between the pons and the porus trigeminus. ${ }^{28,29}$ The objective of the present study is to evaluate the efficacy of IN in patients with TN without NVC and evaluate the longterm outcome.

\section{Materials and Methods}

This is an observational prospective cohort study, based on the prospective observation of 184 patients diagnosed with TN (TN Type 1). The patients were treated by posterior fossa exploration, during the period between April 2012 and October 2019.

Sixteen of the patients were excluded from the present study due to the diagnosis of a cerebellopontine angle tumor during the preoperative evaluation, using magnetic resonance imaging (MRI) of the brain. Data was obtained from hospital records and patient interviews.

Patients included in the cohort study were diagnosed with TN (TN type 1), characterized by paroxysmal and lancinating pain in the distribution area of the trigeminal nerve branches. These patients experienced unilateral, recurrent, stereotyped attacks, generally provoked by stimulated trigger points, including facial movements and changes in temperature.

Indications for surgery included insufficient pain relief with drug treatment and or unacceptable medication side effects. Surgical procedures involved MVD and percutaneous procedures (balloon compression and radiofrequency thermocoagulation).

General physical and neurological examinations were clinically performed to evaluate the patients. In addition, brain MRI, in combination with three high-resolution sequences (T2-weighted 3D, 3D TOF-MRA, and 3D T1-Gad) with fine cuts in the trigeminal nerves, were used for detection of possible neurovascular contact. Routine presurgical examinations were performed.

A surgical treatment algorithm was used for patients with TN ( - Fig. 1). The advantages and disadvantages of the different surgical treatment options were explained to the patients, and they decided according to their preference. Only those who chose MVD were included in the present study.

The 170 patients with trigeminal neuralgia were divided into two groups. The first group, Group A, consisted of 50 patients who were treated with internal neurolysis (IN). Group B was made up of 120 patients treated with MVD (4 patients treated with MVD and IN). Each group had one patient who underwent two procedures at different times for bilateral trigeminal neuralgia, which was considered to be a separate case for the purposes of analysis. Only one patient (2\%) in Group A had a previous surgery. This patient had undergone two percutaneous balloon surgeries without adequate response in pain management. The follow-up period was from 6 months to 7.5 years (average 4 years). In patients with recurrence, the time at which the recurrence occurred was considered a follow-up endpoint.

The Barrow Neurological Institute (BNI) pain intensity score and facial numbness score table was used in the postoperative evaluation (-Table 2 ). The grade of NVC was established on a scale from I to III. In grade I, the vessel was in contact with the root without any visible indentation at the root. In grade II, there was root displacement and/or distortion, and in grade III there was marked indentation in the root. The absence of contact or compression in the root was recorded as grade 0 . 


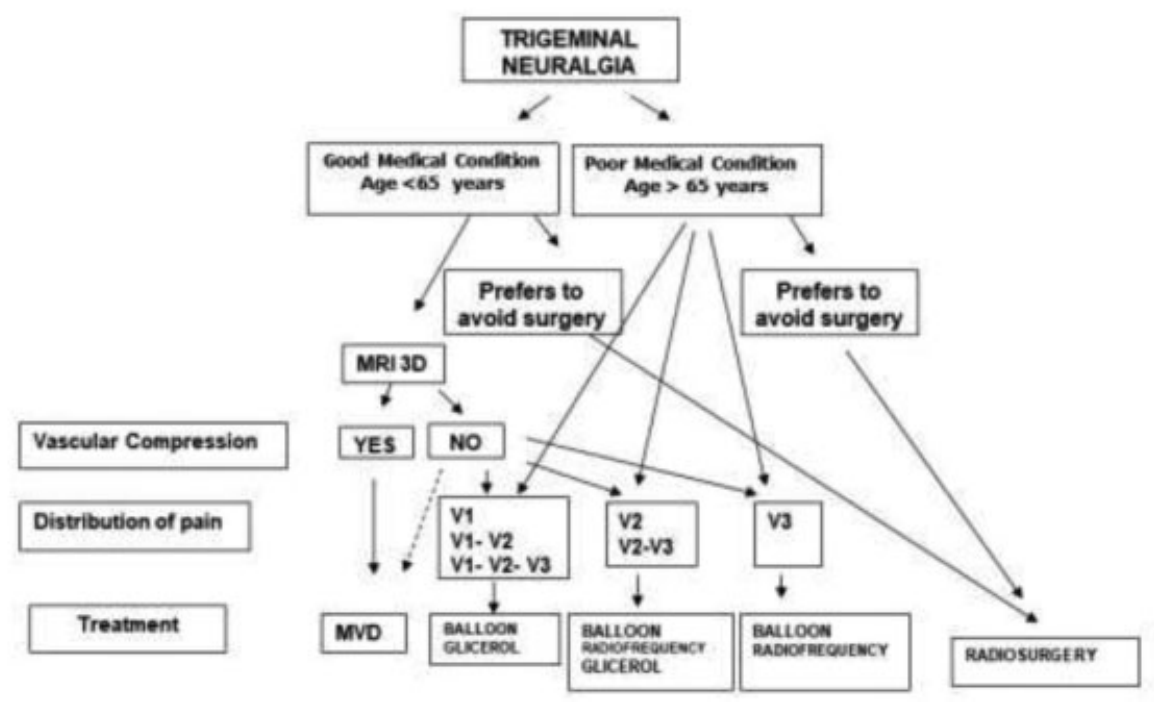

Fig. 1 Algorithm of surgical treatment for trigeminal neuralgia.

Table 2 Barrow Neurological Institute (BNI) pain intensity score and facial numbness score

\begin{tabular}{|c|c|}
\hline \multicolumn{2}{|r|}{ (P) Evaluation of pain relief by the BNI pain intensity score } \\
\hline 1 & No pain, no medication \\
\hline 2 & Occasional pain, not requiring medication \\
\hline 3 & Some pain, adequately controlled with medication \\
\hline 4 & Some pain, not adequately controlled with medication \\
\hline 5 & Severe pain / no pain relief \\
\hline \multicolumn{2}{|r|}{$\begin{array}{l}\text { (N) Evaluation of numbness by the BNI facial numbness } \\
\text { score }\end{array}$} \\
\hline 1 & No facial numbness \\
\hline 2 & Mild facial numbness, not bothersome \\
\hline 3 & Facial numbness, somewhat bothersome \\
\hline 4 & Facial numbness, very bothersome \\
\hline
\end{tabular}

\section{Statistical Analysis}

Epidemiological data, clinical history, operative findings, and clinical results were analyzed.

The data was stored on a Microsoft Excel (Microsoft Corporation, Redmond, WA, USA) spreadsheet. The mean, standard deviation (SD), minimum and maximum values were used to summarize the quantitative variables. To summarize the qualitative variables, frequency tables (simple and crossed) were used, expressing the final results in absolute and relative frequency. Ratio comparison test and Kaplan-Meier curves were calculated to determine the ratio of patients who responded to the operation. All hypothesis tests were performed considering a type I error $(\alpha)$ equal to 0.05. Statistical analysis was performed by the R version 4.0.2 statistical software (R Foundation, Vienna, Austria).

\section{Surgical Procedure}

The patients were placed in supine or in lateral decubitus position with the affected side upward, the ear positioned parallel to the floor, and the chin flexed. A linear $3.5 \mathrm{~cm}$ incision was made behind the ear, starting at the top of the pinna and extending to the mastoid tip within the hairline, between $\sim 4$ and $5 \mathrm{~cm}$.

The burr hole was made in the asterion, and a $3 \times 3 \mathrm{~cm}$ retrosigmoid craniotomy is performed using a high-speed drill and Kerrison Rongeurs to expose the borders of the transverse sinus, the sigmoid sinus, and their intersection. Any exposed mastoid air cells were carefully waxed. The dura was opened in a rectangular fashion along the inferior border of the transverse sinus with the base toward the sigmoid sinus. The dural edges were elevated with sutures extended over the craniotomy dressings. Under direct microscopic visualization, gentle traction of the cerebellum took place with an aspirator and bipolar, protected by cottonoids. Meticulous arachnoid dissection was made and cerebral spinal fluid (CSF) was aspirated.

The superior petrosal vein and its main branches were dissected free from the surrounding arachnoid membranes and preserved as much as possible. The entire length of the trigeminal nerve from the pons to the Meckel cave was carefully explored even if a definite vessel was located. Conflicting vessels were dissected and separated from the nerve, a teflon felt was implanted between them. Particular attention was made to prevent a "neo-compression" between the prosthetic material and the nerve root.

When a vascular compression was not found; veins with simple contact or thickness arachnoid adhesions affected branches of the trigeminal nerve, according to preoperative pain location and intraoperative findings, were longitudinally divided along its fibers, using a Rothon microdisector, into 3 to 4 bundles from the root entry point (REP) to the porus 


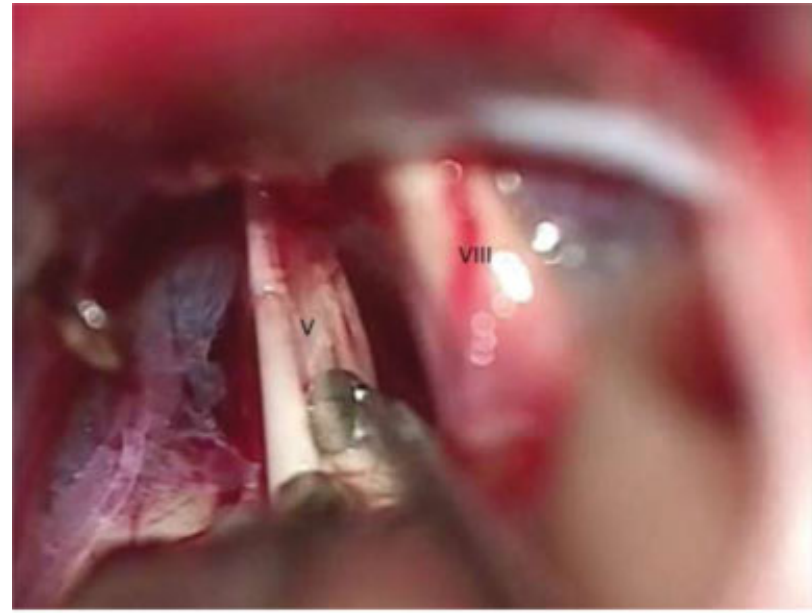

A

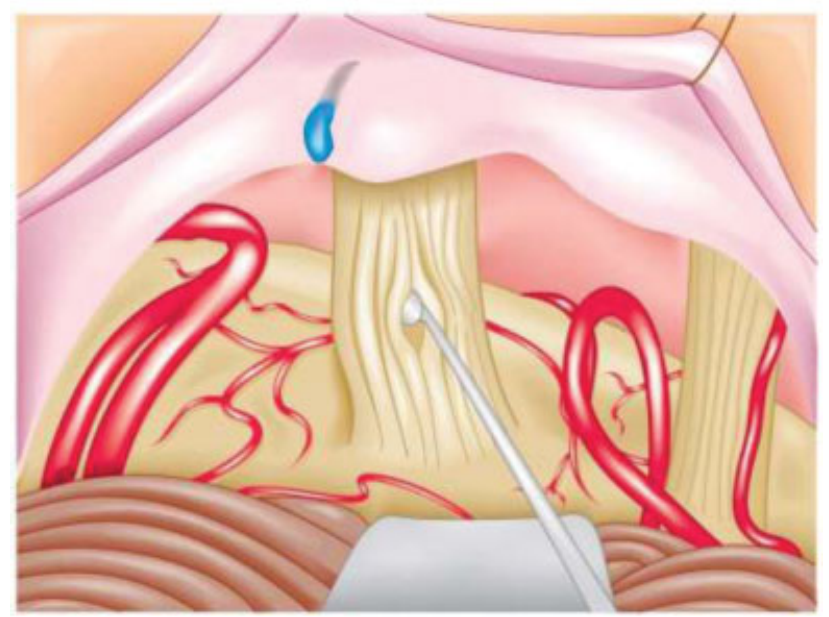

B

Fig. 2 Internal neurolysis (IN) for trigeminal neuralgia without neurovascular compression. (A) IN procedure with longitudinal division of the trigeminal nerve using a microdissector. (B) An anatomical drawing of the IN procedure.

trigeminus (-Fig. 2). Finally, compression of the root at the root entry zone (REZ) with bipolar forceps for 10 seconds took place. The dura was closed, filling the craniotomy defect with autogenous bone. Closure of muscle, soft tissue, and skin was performed in layers in a standard fashion.

\section{Results}

In the present study, 50 internal neurolysis procedures were performed in patients with $\mathrm{TN}$ during the period between April 2012 and October 2019. Of these patients, 40 were female (80\%), the age ranged from 25 to 75 years old (mean of 49 years old).

The age distribution according to gender was unimodal (-Fig. 3). The most affected side of the face was the right (68\%), the most affected branches being the combination V2, V3 (50\%). These clinical and demographic characteristics are shown in - Table 3 and - Table 4. The degree of NVC severity is shown in - Table 5. In this series, we found 42 cases (24.7\%) with absence of neurovascular conflict.

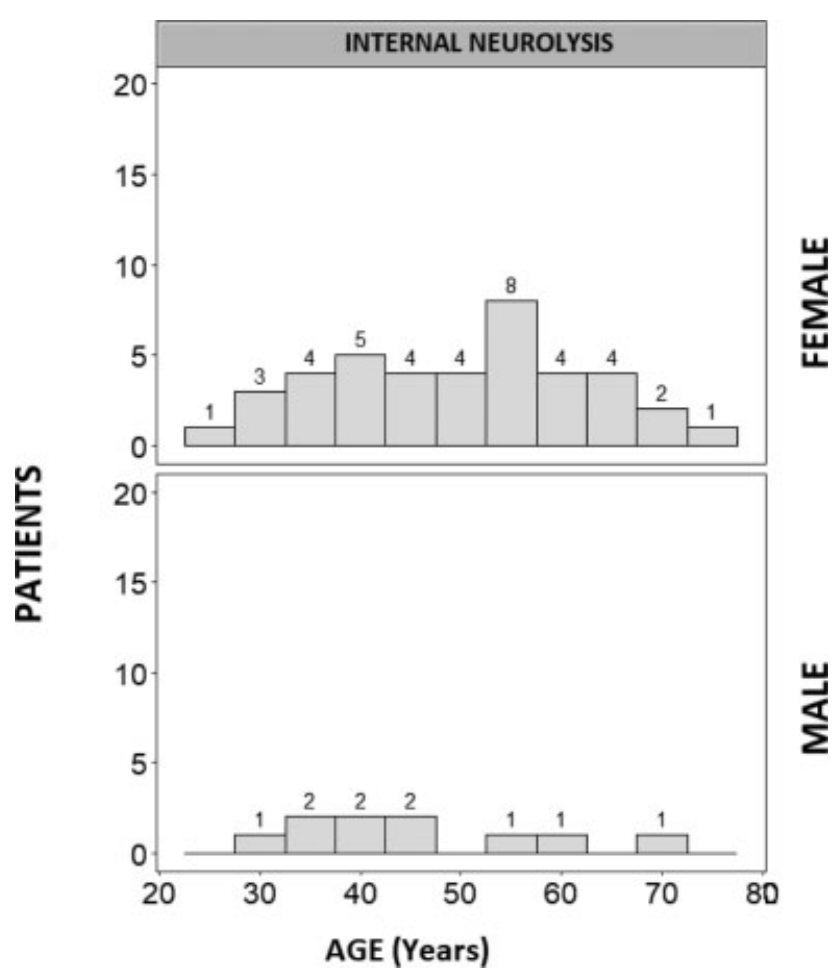

Fig. 3 The Hartigans Dip Test for Unimodality indicates that the age distribution according to gender was unimodal, female $(p=0.227)$ and male $(p=0.220)$.

Table 3 Demographic and clinical information of the two groups

\begin{tabular}{|l|l|l|}
\hline FEATURE & $\begin{array}{l}\text { GROUP A } \\
(\boldsymbol{n}=\mathbf{5 0})\end{array}$ & $\begin{array}{l}\text { GROUP B } \\
(\boldsymbol{n}=120)\end{array}$ \\
\hline AGE (years old) & $49(25-75)$ & $50.8(23-76)$ \\
\hline SIDE (Right/Left) & $34 / 16$ & $87 / 33$ \\
\hline GENDER (Female /Male) & $40 / 10$ & $79 / 41$ \\
\hline DISTRIBUTION OF PAIN & & \\
\hline V1 & 0 & 0 \\
\hline V2 & $6(12 \%)$ & $13(10.8 \%)$ \\
\hline V3 & $9(18 \%)$ & $27(22.5 \%)$ \\
\hline V1,V2 & $2(4 \%)$ & $10(8.3 \%)$ \\
\hline V2,V3 & $25(50 \%)$ & $51(42.5 \%)$ \\
\hline V1,V2,V3 & $8(16 \%)$ & $19(15.8 \%)$ \\
\hline
\end{tabular}

Group A: Patients without vascular compression, Group B: Patients with vascular compression.

Surgical findings in Group A included 42 patients (84\%) with no neurovascular conflicts found. Although no neurovascular conflicts were detected, there was presence of arachnoid thickening in 11 patients. The remaining 8 patients (16\%) presented with a vein with simple contact (grade 1) to the trigeminal root; 2 of those patients also presented thickened arachnoid adhesions.

In Group B, 116 patients (96.7\%) with distortion/displacement (grade II) or indentation (grade III) were surgically treated with MVD; while 4 patients (3.3\%) with touching or less severe compression (grade I) underwent an MVD in combination with an IN (- Table 5). 
Table 4 Distribution of patients with internal neurolysis according to age

\begin{tabular}{|l|l|l|}
\hline AGE (years old) & Patients & $\%$ \\
\hline$\leq 30$ & 4 & 8 \\
\hline $31-40$ & 9 & 18 \\
\hline $41-50$ & 12 & 24 \\
\hline $51-60$ & 15 & 30 \\
\hline $61-70$ & 8 & 16 \\
\hline $71-80$ & 2 & 4 \\
\hline TOTAL & 50 & 100 \\
\hline
\end{tabular}

Table 5 Distribution of patients according to the grade of severity of neurovascular contact

\begin{tabular}{|l|l|l|l|}
\hline GRADE & $\begin{array}{l}\text { Group A } \\
(\boldsymbol{n}=\mathbf{5 0})\end{array}$ & $\begin{array}{l}\text { Group B } \\
(\boldsymbol{n}=\mathbf{1 2 0})\end{array}$ & $\begin{array}{l}\text { TOTAL } \\
(\boldsymbol{n}=\mathbf{1 7 0})\end{array}$ \\
\hline $\mathbf{0}$ & $42(84 \%)$ & 0 & $42(24.7 \%)$ \\
\hline I & $8(16 \%)$ & $4(3.3 \%)^{*}$ & $12(7 \%)$ \\
\hline II & 0 & $99(82.5 \%)$ & $99(58.2 \%)$ \\
\hline III & 0 & $17(14.2 \%)$ & $17(10 \%)$ \\
\hline
\end{tabular}

Group A: Internal neurolysis, Group B: Microvascular decompression. ${ }^{*} \mathrm{MVD}$ and internal neurolysis were performed.

During the manipulation of the trigeminal nerve, and while IN was performed; some patients experienced bradicardia and arrhythmias that reversed spontaneously. None of these cases reported recurrent bradicardia or arrhythmias requiring any additional treatment.

In the postoperative period, 44 patients (88\%) who underwent IN surgical treatment were pain free without any medication, 3 (6\%) experienced occasional pain, but did not require medication. Mild facial numbness not bothersome to the patient was presented in $88 \%$ of the cases, which resolved in 6 months, on average. (-Table 6). In Group B, $94.2 \%$ of the

Table 6 Surgical results after surgery using BNI pain intensity score and facial numbness score

\begin{tabular}{|c|l|l|}
\hline SURGICAL RESULTS & $\begin{array}{l}\text { GROUP A } \\
(n=50)\end{array}$ & $\begin{array}{l}\text { GROUP B } \\
(n=120)\end{array}$ \\
\hline (P) Pain intensity score & $44(88 \%)$ & $113(94.2 \%)$ \\
\hline 1 & $3(6 \%)$ & $2(1.7 \%)$ \\
\hline 2 & 0 & $1(0.8 \%)$ \\
\hline 3 & 0 & $1(0.8 \%)$ \\
\hline 4 & $3(6 \%)$ & $3(2.5 \%)$ \\
\hline 5 & 0 & $104(86.7 \%)$ \\
\hline (N) Facial numbness score & $11(9.2 \%)$ \\
\hline 1 & $44(88 \%)$ & $5(4.1 \%)$ \\
\hline 2 & $4(8 \%)$ & 0 \\
\hline 3 & $2(4 \%)$ & \\
\hline 4 & \multicolumn{2}{|l}{} \\
\hline
\end{tabular}

Group A: Internal neurolysis, Group B: Microvascular decompression.

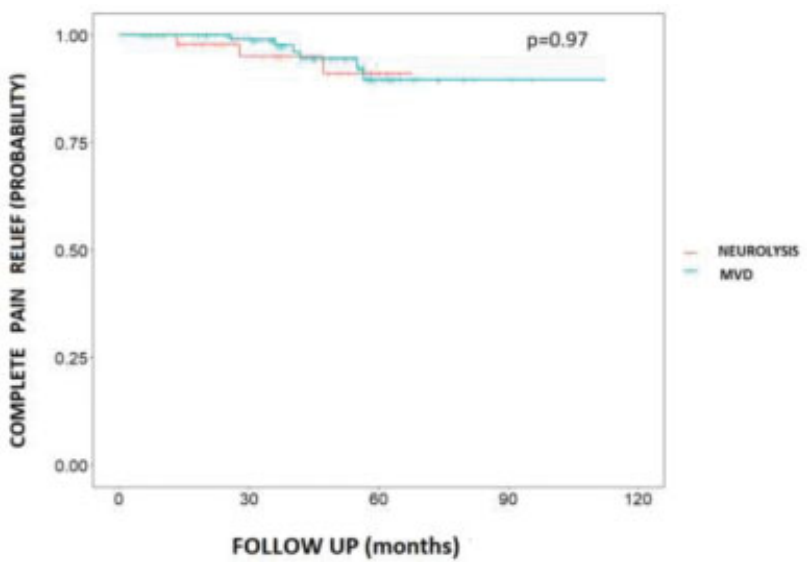

Fig. 4 Kaplan-Meier curves showed that the mean pain-free time was 84.9 (standard error: 2.82) months for neurolysis. For microvascular decompression, the mean was 85.4 (standard error: 1.86) months. The logarithm of range test ("logrank") shows that the treatments did not show differences throughout the study time with respect to complete pain relief $(p=0.97)$.

patients who underwent MVD were pain-free, and 16 patients (13.3\%) experienced some grade of facial numbness, 4 of them having been treated with DMV and IN surgeries.

Recurrence was defined as transition from pain-free or occasional pain without medication (BNI I and II) to severe pain or requirement of medication (BNI III-V).

The follow-up period was from 6 months to 7.5 years (average 4 years). In group A there was recurrence in 3 patients (6\%), one of them with intraoperative finding of a small vein that contacted the trigeminal root, occurred at 12 months; a second patient in whom only adhesions were found recurred at 25 months, and a third patient in whom no neurovascular compression was identified, it recurred at 44 months. Two out of three patients underwent successful balloon compression, and the third continued with medication.

The mean time of recurrence was 27 months. KaplanMeier analysis showed that the mean pain-free time was 84.9 (standard error: 2.82) months (-Fig. 4).

The recurrence in Group B was of 5.8\% in this follow-up period.

The logarithm of range test ("Logrank") shows that the treatments in the 2 groups did not show differences over time in the study with respect to complete pain relief $(p=0.97)$.

Complications are summarized in - Table 7. Cerebellar infarction occurred in one patient who also had hemifacial

Table 7 Postoperative complications

\begin{tabular}{|l|l|l|}
\hline COMPLICATION & Group A & Group B \\
\hline Cerebellar infarction & $1(2 \%)$ & \\
\hline Transient hearing loss & $1(2 \%)$ & $2(1.7 \%)$ \\
\hline Meningitis & & $1(0.8 \%)$ \\
\hline Transient diplopia & & $1(0.8 \%)$ \\
\hline Wound cerebrospinal fluid leak & & $2(1.7 \%)$ \\
\hline Nasal cerebrospinal fluid leak & & $2(1.7 \%)$ \\
\hline
\end{tabular}

Group A: Internal Neurolysis, Group B: Microvascular decompression. 
spasm and had to undergo MVD of the facial nerve during the same procedure. Most of the patients experienced mild transient hearing loss, with resolution in 2 months; the diplopia was caused by paresis of the VI cranial nerve, with complete resolution after 3 months. In cases of nasal CSF leaks, external lumbar drainage was placed for between 5 and 7 days. In 2 cases of wound CSF leaks, placement of new sutures were required, as well as compression and use of acetazolamide. Placement of external lumbar drain was not necessary.

\section{Discussion}

\section{Pathophysiology}

The leading theory for the pathophysiology of TN is the "ignition" hypothesis proposed by Devor et al in 2002, which proposes three key elements in the genesis of $\mathrm{TN}$ : a trigger, an amplifier, and a stop mechanism. ${ }^{30}$

According to the ignition hypothesis, a neurovascular contact is thought to damage the myelin sheath in the trigeminal nerve, which renders the sensory afferents hyperexcitable by means of ectopic pacemaker sites and ephaptic cross-talk and crossed after discharge between axons. ${ }^{30,31}$ Anatomical studies confirmed that the root entry zone or transition zone of the trigeminal nerve, where the myelination changes from peripheral Schwann cell myelination to central oligodendrocyte myelination, is a site of demyelination in patients with classical TN with a neurovascular contact. ${ }^{32,33}$

Currently accepted, the decompression of the central myelin alone or decompression of the central-peripheral myelin transitional zone was the mechanism that provided pain relief.

McLaughlin et al., in 1999, postulated that the central myelin of the sensory root of the trigeminal nerve could extend along the entire cisternal segment of this branch. He stated that not only would vascular decompression of the REZ relieve the pain of patients with $\mathrm{TN}$, but also that decompression performed anywhere along the entire length of the nerve (from the pons to entry into the Meckel cave) would be effective. ${ }^{34}$

Sindou et al., in 2002, suggested that NVC can be located not only at the REZ but also all along the root, and because offending vessels can be multiple in the same patient, he strongly advised that the entire trigeminal nerve from the Meckel cave to the pons should be exposed. He proposed that NVC probably does not entirely explain all the pathogenesis of TN. He thought that there might be several other important factors. Sindou concluded, "It is wise to admit that besides peripheral mechanisms, central phenomena probably play an important additional role." 16

Peker et al., in 2006, reported his study of one hundred trigeminal nerves from 50 cadaver heads that were examined. "The measurements showed that the central myelin occupies only the initial one-fourth of the trigeminal nerve length. If trigeminal neuralgia is caused exclusively by vascular compression of the central myelin, the problem vessel would always have to be located in this region. However, it is well known that pain from trigeminal neuralgia can resolve after vascular decompression at more distal sites. This sug- gests that the effects of surgical decompression are caused by another mechanism." 32

Ko, Lee et al. observed that it is increasingly clear that TN occurs and recurs in the absence of NVC, ${ }^{35}$ and that NVC of the trigeminal nerve exists in a sizeable population without TN. ${ }^{36}$ He suggested that NVC is neither a necessary nor sufficient condition for the development of TN. Nevertheless, NVC does play a role in disease pathogenesis.

It is becoming increasingly understood that the pathophysiology of TN is associated with both trigeminal nerve and brain abnormalities.

\section{Importance of Degree of Neurovascular Compression}

Increasingly, the contributions of NVC severity is beginning to be better understood.

Sindou reported a series of 362 patients who underwent MVD. Concerning anatomical factors, neither the type of the compressive vessel nor its location along or around the root was found to be significant. However, the severity of compression was important - the more severe the degree of compression, the better the outcome. ${ }^{37}$

Maarbjerg et al., in 2015, with 3T MRI, evaluated 135 patients with classical trigeminal neuralgia. Neurovascular contact was prevalent both on the symptomatic and asymptomatic side, 89 versus 78\%, while severe neurovascular contact (displacement or atrophy of the trigeminal nerve) was highly prevalent on the symptomatic compared with the asymptomatic side (53 versus 13\%). Severe neurovascular contact was caused by arteries in $98 \%$.

This concluded that neurovascular contact causing displacement or atrophy of the trigeminal nerve is highly associated with the symptomatic side in classical TN, as opposed to neurovascular contact in general, suggesting that the degree of NVC could thus be important when selecting patients for surgery. ${ }^{38}$

Hughes et al. published in 2019 the significance of degree of NVC in surgery for TN. Seventy-nine patients were studied on a 3-T MRI. Vascular contact was more common on the asymptomatic side $(43 / 79,54.4 \%)$ compared with the symptomatic side (30/79, 38\%). Severe NVC (indentation/deformity of the of the trigeminal nerve) was much more commonly identified on the symptomatic side $(47 / 79,59.5 \%)$ compared with the asymptomatic side (7/79, 8.9\%). In his study, the only imaging variable that was a statistically significant predictor of being pain-free without medication following MVD was severe NVC. Patients with severe NVC were 6.36 times more likely to be pain-free following MVD when compared with those without severe NVC. ${ }^{39}$

According to various studies published with high resolution MRI, the presence of NVC has a sensitivity of $87 \%$ to $97 \%$ and a specificity between $50 \%$ to $100 \%$ for $\mathrm{TN}^{23,35,39,40}$

Recently, it was reported that ultra-high field MRI enabled advanced Diffusion tensor imaging (DTI)-based tractographic reconstruction of the white matter tracts connecting the thalamus and primary somatosensory cortex. Reduced microstructural integrity of thalamic-somatosensory tracts was found ipsilateral to the site of NVC in patients with TN, whereas no differences were observed contralateral to the 
site of NVC. These changes implicate a compensatory mechanism for reducing pain sensation, and may provide substantial evidence of secondary white matter disruption at the thalamic-somatosensory level in patients with TN. ${ }^{41}$

\section{Trigeminal Neuralgia without Vascular Compression}

The absence of vascular compression over the trigeminal nerve has been described in the literature in 9 to $23.7 \%$ of cases (-Table 1). In our series of 170 patients, 42 (24.7\%) presented no vascular conflict, and in 12 cases (7\%), a mild contact (grade I) was found; 8 with venous compression were coagulated and cut and IN was performed. In 4 cases with arterial compression, MVD in combination with IN was performed.

It is likely that the number of TN without neurovascular compression (WONVC) will increase more since it is increasingly recognized that vascular contact (grade I) should not be accepted as vascular compression and additional treatment must done.

In the absence of NVC on imaging, the question arises as to whether recommend a posterior fossa exploration versus percutaneous procedures or radiosurgery.

However, it is challenging for neurosurgeons to deal with cases without visible vascular compression intraoperatively, and there are no well-designed surgical strategies for these patients, which ranged from no manipulation to complete section of the nerve.

In these cases, most neurosurgeons do a meticulous dissection of the arachnoid to expose the entire trigeminal root, followed by a massage and/or a compression with bipolar to the trigeminal nerve or a partial nerve section.

Based on the proposed mechanisms of production of TN related to the compression of the sensitive trigeminal root of the trigeminal nerve in its intracranial route, nondestructive open surgical techniques have historically been directed toward a decompression of the trigeminal nerve at some point in its intracranial trajectory. ${ }^{42,43}$

In 1955, Shelden et al. suggested that the common denominator to all procedures is operative trauma, introducing a new technique such as pressing with a blunt dissector the portio major nerve fibers of the trigeminal nerve surgically exposed through a middle cranial fossa approach, suggesting that the compression of the trigeminal fibers during the operation is the factor that relieves the pain. ${ }^{44}$

Partial sensory rhizotomy (PSR) is a classical alternative technique used in the absence of NVC.

The response rate is reported in 70 to $87 \%$ of patients ( - Table 8 ), with a recurrence rate of $29 \%$ at 5 years of follow-up. ${ }^{21,45-48}$ The main disadvantages of this ablative treatment are sensory deficits, which occur in 22 to $100 \%$ of patients and can lead to additional complications as dysesthesias, corneal reflex impairment and anesthesia dolorosa. Furthermore, it has been reported that a lesser degree of patient satisfaction is associated with side effects after PSR. ${ }^{47}$

Ishikawa et al., in 2002, speculated a different mechanism other than vascular compression. ${ }^{49}$

They suggested that arachnoid thickening or granulomatous adhesion between the root and surrounding structures can cause a tethering effect to the trigeminal root, which would make pulsatile movement of the root more restricted or desynchronized. This could give the root an abnormally high stretching force, which might promote hyperexcitability of the nerve.

Dissection of thick arachnoid around the root along the whole length reversed the root to be straight and flaccid. This speculative mechanism suggests that it is important to make

Table 8 Partial sensory rhizotomy. Results related to extent of the rhizotomy

\begin{tabular}{|c|c|c|c|c|c|c|c|c|}
\hline Reference & $\begin{array}{l}\text { Number } \\
\text { of Cases }\end{array}$ & $\begin{array}{l}\text { Pain Relief } \\
\text { After } \\
\text { Surgery (\%) }\end{array}$ & $\begin{array}{l}\text { Median } \\
\text { Follow-Up } \\
\text { (months) }\end{array}$ & $\begin{array}{l}\text { Extent of } \\
\text { Rhizotomy }\end{array}$ & $\begin{array}{l}\text { Corneal Reflex } \\
\text { Impairment/ } \\
\text { Hypesthesia } \\
(\%)\end{array}$ & $\begin{array}{l}\text { Sensory } \\
\text { Deficit (\%) }\end{array}$ & $\begin{array}{l}\text { Anesthesia } \\
\text { dolorosa }\end{array}$ & $\begin{array}{l}\text { Recurrence } \\
\text { Rate }\end{array}$ \\
\hline $\begin{array}{l}\text { Adams et al. }{ }^{45} \\
\text { J Neurol Neurosurg } \\
\text { Psychiatry } 1982\end{array}$ & 54 & 87.3 & 54 & $\begin{array}{l}30-100 \% \text { of } \\
\text { trigeminal } \\
\text { Nerve }\end{array}$ & 0 & $\begin{array}{l}100 \\
\text { Painful } \\
\text { dysesthesia } \\
7.4 \%\end{array}$ & 1 case $(1.8 \%)$ & $\begin{array}{l}11.8 \% \\
\text { at } 5 \text { years }\end{array}$ \\
\hline $\begin{array}{l}\text { Klun et al. } \\
\text { Neurosurgery } 1992\end{array}$ & 42 & 86 & 62.4 & $\begin{array}{l}1 / 3 \text { or less } \\
\text { of the pars } \\
\text { major }\end{array}$ & 0 & 100 & 0 & $\begin{array}{l}\text { Total } \\
\text { recurrence } \\
\text { rate } 49 \%\end{array}$ \\
\hline $\begin{array}{l}\text { Young et al. }{ }^{46} \\
\text { J Neurosurg } 1993\end{array}$ & 83 & $\begin{array}{l}48 \text { Excellent } \\
22 \text { Good }\end{array}$ & 72 & $\begin{array}{l}1 / 3 \text { to } 1 / 2 \\
\text { ventrolateral of } \\
\text { nerve root }(89 \%) \\
2 / 3 \text { of nerve } \\
\text { root }(11 \%)\end{array}$ & NA & 67 & NA & $\begin{array}{l}17 \% \text { at } \\
1 \text { year and } \\
2.6 \% \text { each } \\
\text { year } \\
\text { thereafter }\end{array}$ \\
\hline $\begin{array}{l}\text { Zakrzewska et al. }{ }^{47} \\
\text { Neurosurgery } 2005\end{array}$ & 60 & 88 & 68.4 & NA & $\begin{array}{l}22 \text { "eye } \\
\text { problems" }\end{array}$ & 48 & NA & $\begin{array}{l}28 \% \text { at } \\
5 \text { years }\end{array}$ \\
\hline Terrier et al. ${ }^{48} 2017$ & 22 & 86.4 & 67.3 & $\begin{array}{l}2 / 3 \text { ventrolateral } \\
\text { of pars } \\
\text { Major }\end{array}$ & 0 & 22.7 & $\begin{array}{l}9 \% \text { in } \\
\text { hemitongue }\end{array}$ & $\begin{array}{l}14.6 \% \\
\text { at } 1 \text { year } \\
31.5 \% \\
\text { at } 5 \text { years }\end{array}$ \\
\hline
\end{tabular}

Abbreviations: MVD, microvascular decompression; NA, not available; PSR, partial sensory rhizotomy. 
Table 9 Series of intraoperative trigeminal root manipulations

\begin{tabular}{|l|l|l|l|l|l|}
\hline Reference & $\begin{array}{l}\mathrm{N}^{\circ} \text { of } \\
\text { cases }\end{array}$ & Treatment & $\begin{array}{l}\text { Pain-free } \\
\text { immediatly }\end{array}$ & Recurrence & Facial numbness \\
\hline $\begin{array}{l}\text { Ishikawa et al. } \\
\text { Journal of Clinical } \\
\text { Neuroscience } 2002\end{array}$ & 5 & Arachnoidal dissection & $80 \%$ & $20 \%$ in 15 months & NR \\
\hline $\begin{array}{l}\text { Revuelta et al. }{ }^{24} \text { World } \\
\text { Neurosurgery } 2013\end{array}$ & 44 & $\begin{array}{l}\text { Intermittent compression } \\
\text { on cisternal segment }\end{array}$ & $100 \%$ & $27.2 \%$ in 10 months & $61.4 \%$ transient \\
\hline $\begin{array}{l}\text { Cheng et al. }{ }^{51} \text { Acta } \\
\text { Neurochir } 2015\end{array}$ & 28 & $\begin{array}{l}\text { Compression with bipolar } \\
\text { forceps for } 10 \text { seconds }\end{array}$ & $71.4 \%$ & $38.4 \%$ in 46 months & $21.4 \%$ transient \\
\hline $\begin{array}{l}\text { Guo et al. } \\
\text { Journal of Clinical } \\
\text { Neuroscience } 2018\end{array}$ & 19 & $\begin{array}{l}360 \text {-degree circumferential } \\
\text { arachnoid dissection }\end{array}$ & $100 \%$ & $10.5 \%$ in 2 years & $15.8 \%$ transient \\
\hline $\begin{array}{l}\text { Urculo et al. } \\
\text { Neurocirugia } 2020\end{array}$ & 10 & $\begin{array}{l}\text { Trigeminal root massage/ } \\
\text { intermittent compression }\end{array}$ & $100 \%$ & $40 \%$ in 5 years & NR \\
\hline
\end{tabular}

Abbreviation: NR, not reported.

the root free along the entire length, especially at its distal portion in cases with no offending vessels.

Revuelta-Gutierrez et al., in 2006 and 2013, proposed their surgical strategy for TN without vascular compression. The surgery consists of meticulous dissection of the arachnoid, exposing the entire trigeminal root, followed by gentle compression with bipolar tips on its cisternal segment. ${ }^{24,50}$

This nerve compression technique has been subsequently followed by other authors. ${ }^{51,52}$

- Table 9 shows the outcome of a series of intraoperative trigeminal root manipulations.

\section{Internal Neurolysis}

Nerve combing is a surgical strategy for trigeminal neuralgia that longitudinally splits branches of the trigeminal nerve using a special fiber knife in accordance with preoperative pain locations and intraoperative findings. This surgical strategy for TN was reported by Li et al. in 1995. ${ }^{53}$

Ashkan et al., in 2004, reported their series of MVD for TN in 80 patients, "When no compressing vessel was identified, the trigeminal nerve was probed longitudinally by use of a microdissector and split into several fascicles. To the best of our knowledge, this is a novel technique and is preferred by the authors to the partial transverse sectioning of the nerve, which is usually associated with facial numbness." ${ }^{54}$ About 13 patients were subjected to these techniques, without specific mention of the surgical outcome of these patients

Ma et al., in 2009, described 10 patients without vascular compression who underwent nerve combing and achieved satisfactory long-term relief by $70 \%$. They postulated that traumatizing the nerve and dampening its abnormal activity in the brainstem could perhaps explain nerve combing to relieve pain. ${ }^{28}$

The mechanism by which IN results in pain relief remains unclear. Studies suggest that IN destroys the continuity of axons and decreases the electrical excitability of abnormal afferent trigeminal fibers, permanently degenerating the partial axon tissue and myelin sheath after a period of time. 29,55
Internal neurolysis may disrupt interconnections between nerve fibers and communication between distributions of the trigeminal nerve prior to entrance into the brainstem. ${ }^{25}$ Kline et al. suggested that partial nerve injury and damage to the root of the trigeminal nerve mediated pain relief. ${ }^{56}$

Internal neurolysis resulted in immediate relief of all pain in 80 to $98 \%$ of patients (-Table 10 ).

The success rate is durable, with an estimated 72 to $82 \%$ pain-free in 5 years. ${ }^{25,27,29,55,57}$

Microvascular decompression has an initial pain relief rate of 79 to $94 \%,{ }^{14-16,39}$ with a pain-free rate of 72 to $84 \%$ at a 5-year follow-up. ${ }^{47,58-60}$

In our series, the two proportion Z-Test showed no statistically significant difference in immediate $(p=0.289)$ and long-term outcomes $(p=1.000)$ between IN and MVD.

All of our patients with IN had some degree of hypoesthesia; in two, the facial numbness was very bothersome in the immediate postoperative period, but they improved afterwards.

In $88 \%$ of the cases, sensitivity was fully recovered within 6 months after the operation. Compared with our patients with balloon compression, the degree of numbness is generally much lower in patients with IN at the immediate postoperative. Reported rates of facial numbness after IN range between 60 and 96\%. ${ }^{25,27,28,61-63}$ Most cases are transient and resolve over weeks to months.

A previous study reported that facial numbness after IN did not negatively impact the quality of life in the majority of cases when the pain was controlled. ${ }^{62}$

One case of anesthesia dolorosa reported in the literature includes a patient with previous MVD for the treatment of TN, who presented with a sensory deficit. ${ }^{25}$

Some studies found that patients with TN without NVC may represent a distinct population of younger, predominantly female patients in their mid-30s with a short symptom duration. ${ }^{64,65}$

In our patients undergoing IN, the difference in the mean age according to gender was not statistically significant $(p=0.335)$. The age distribution of our female patients shows for the IN procedure an almost uniform dispersion 
Table 10 Literature series of Internal Neurolysis (nerve combing) for trigeminal neuralgia

\begin{tabular}{|c|c|c|c|}
\hline Reference & $\begin{array}{l}\text { Number } \\
\text { of cases }\end{array}$ & Outcome & Sensory deficit \\
\hline Ma et al. ${ }^{28}$ Clin J Pain 2009 & 10 & $\begin{array}{l}\text { Initial pain-free: } 80 \% \\
70 \% \text { pain free, } \\
\text { recurrence } 10 \% \text { in } 3 \text { years }\end{array}$ & $\begin{array}{l}90 \% \text { transitory numbness } \\
10 \% \text { permanent } \\
\text { numbness }\end{array}$ \\
\hline $\begin{array}{l}\text { Jie et al. } \\
\text { Acta Neurochir } 2013\end{array}$ & 28 & $\begin{array}{l}82 \% \text { pain-free, } \\
4 \% \text { recurrence in } 4.3 \text { years }\end{array}$ & $10.5 \%$ numbness \\
\hline $\begin{array}{l}\text { Ko et al. }{ }^{25} \\
\text { JNS } 2015\end{array}$ & 27 & $\begin{array}{l}\text { Initial pain-free } 85 \% \text {. } \\
72 \% \text { in } 5 \text { years }\end{array}$ & $\begin{array}{l}96 \% \text { numbness } \\
1 \text { patient (4\%) anesthesia dolorosa * }\end{array}$ \\
\hline $\begin{array}{l}\text { Zhou et al. }{ }^{57} \\
\text { Braz J Otorhinolatyngol } 2016\end{array}$ & 50 & $\begin{array}{l}\text { Initial satisfactory relief } 92 \% \\
82 \% \text { in } 7.5 \text { years } \\
\text { Recurrence } 10 \%\end{array}$ & $16 \%$ dysesthesias \\
\hline $\begin{array}{l}\text { Zhao et al. }{ }^{55} \\
\text { J Craniofacial } 2017\end{array}$ & 15 & $\begin{array}{l}\text { Initial pain-free } 80 \% \\
73.3 \% \text { pain-free in } 4 \text { years }\end{array}$ & $\begin{array}{l}13 \% \text { transitory numbness } \\
7 \% \text { permanent numbness }\end{array}$ \\
\hline $\begin{array}{l}\text { Zhang et al. }{ }^{61} \\
\text { World Neurosurgery } 2017\end{array}$ & 86 & $\begin{array}{l}\text { Initial pain-free } 98 \% \\
94 \% \text { in } 1 \text { year }\end{array}$ & $\begin{array}{l}60 \% \text { transitory numbness at } 1 \text { day } \\
4 \% \text { in } 1 \text { year }\end{array}$ \\
\hline $\begin{array}{l}\text { Liang et al. } \\
\text { Ir J Med Sci } 2017\end{array}$ & 37 & $\begin{array}{l}\text { Initial pain free } 94.6 \% \\
\text { In } 3 \text { years } 78 \% \text { pain free } \\
\text { Recurrence } 21.6 \%\end{array}$ & $\begin{array}{l}91,9 \% \text { transitory facial numbness } \\
\text { In } 6 \text { months } 67.6 \% \text { facial numbness }\end{array}$ \\
\hline $\begin{array}{l}\text { Wu et al. }{ }^{63} \text { Stereotact } \\
\text { Funct Neurosurg } 2018\end{array}$ & 27 & Initial pain free $92.6 \%$ & $88.9 \%$ facial numbness \\
\hline $\begin{array}{l}\text { Yang et al. } \\
\text { Acta Neurol Belg } 2019\end{array}$ & 34 & $\begin{array}{l}\text { Initial pain-free } 88 \% \\
\text { In } 5 \text { years } 73 \% \text { pain-free } \\
\text { Recurrence } 6 \%\end{array}$ & $76 \%$ transitory facial numbness \\
\hline Gonzáles-Portillo et al. 2020 & 50 & $\begin{array}{l}\text { Initial pain-free } 88 \% \\
\text { Recurrence } 6 \%\end{array}$ & $100 \%$ facial numbness $88 \%$ transitory \\
\hline
\end{tabular}

*Previous MVD,

with sensory deficit.

throughout the range of 25 to 75 years old; no outstanding peak was observed. The distribution of the patients in the study of Liang et al. was normal and unimodal. The mean age of the patients was 50.19 years old. ${ }^{62}$

The relapse of TN after MVD has been shown without recurrence of compression. ${ }^{35,66,67}$

Internal neurolysis can be an important option in posterior fossa exploration for recurrent or persistent TN symptoms. Zhang et al. reported that, in patients with recurrent or persistent TN symptoms, IN plus MVD significantly improved the success rate of the operation compared with simple redo MVD. 61

\section{Surgical Description of the Grades of Compression and Location in Microvascular Decompression}

We suggest a surgical description for posterior fossa exploration for TN. - Table 11. It has two components: first, the degree of NVC, based in the studies of Sindou ${ }^{37}$ and Maarbjerg, ${ }^{38}$ and the report of Hughes, who concluded that "The only imaging variable that was a statistically significant predictor of being pain-free without medication following MVD was severe NVC." ${ }^{39}$ The second component is the location of the MVD. The locations were divided in thirds based on the study of Peker et al., ${ }^{32}$ who stated that the cisternal segment of the trigeminal nerve ranged from $8 \mathrm{~mm}$ to $15 \mathrm{~mm}$ long (mean,
Table 11 Surgical description of microvascular decompression for trigeminal neuralgia

\begin{tabular}{|c|l|}
\hline \multicolumn{2}{|l|}{ MICROVASCULAR DECOMPRESSION GRADING SYSTEM } \\
\hline GRADES OF COMPRESSION \\
\hline$\square$ Grade 0 & No contact \\
\hline$\square$ Grade I & $\begin{array}{l}\text { Simple neurovascular contact: without } \\
\text { visible alteration of the root }\end{array}$ \\
\hline$\square$ Grade II & $\begin{array}{l}\text { Severe neurovascular contact: } \\
\text { displacement, distortion, indentation, } \\
\text { engrooving or atrophy of the } \\
\text { trigeminal nerve. }\end{array}$ \\
\hline LOCATION OF NEUROVASCULAR COMPRESSION \\
\hline$\square$ Anterior Third \\
\hline$\square$ Middle Third \\
\hline$\square$ Posterior Third
\end{tabular}

In this grading system, veins are graded according to the same scale as arteries.

The cisternal segment extends from the root entry point to the porus trigeminus.

Posterior Third: Defined as the proximal third of the cisternal segment of the nerve closest to the root entry point.

$12.3 \mathrm{~mm}$; median, $11.9 \mathrm{~mm}$ ). The proportion of the central myelin relative to the length of the cisternal portion of the trigeminal nerve was $25 \%$ in 74 specimens and between 26 and $33 \%$ in 20 specimens out of 100 . 


\section{Conclusions}

Internal neurolysis has become increasingly used as an adjunct or standalone therapy when a low grade or no NVC is identified intraoperatively, or as a salvage procedure in TN patients who are unresponsive to MVD or have a recurrence of symptoms.

Internal neurolysis is a viable treatment option, providing adequate initial pain relief and long-term efficacy.

Patients treated with IN may experience some degree of facial numbness, which was well tolerated by the patients in the present study. However, further studies are required to explore the exact mechanisms of pain relief.

In the present study, there were no statistically significant differences in the immediate and long-term surgical outcomes between IN and MVD.

\section{Conflict of Interests}

The authors have no conflict of interests to declare.

\section{References}

1 Dandy WE. An operation for the cure of tic douloureux. Partial section of the sensory root at the pons. Arch Surg 1929; 18:687-734

2 Dandy WE. The treatment of trigeminal neuralgia by the cerebellar route. Ann Surg 1932;96(04):787-795

3 Dandy WE. Concerning the cause of trigeminal neuralgia. Am J Surg 1934;24:447-455

4 Kaufmann AM, Price AV. A history of the Jannetta procedure. J Neurosurg 2019;132(02):639-646

5 Wilkins RH. Trigeminal Neuralgia: Historical Overview, with Emphasis on Surgical Treatment. In: Burchiel KJ(ed). Surgical management of pain. Thieme; 2002:288-301

6 Wilkins RH. Historical perspectives, in Rovit RL, Murali R, Jannetta PJ (eds). Trigeminal Neuralgia Baltimore: Williams \& Wilkins; 1990:1-25

7 Gardner WJ, Miklos MV. Response of trigeminal neuralgia to decompression of sensory root; discussion of cause of trigeminal neuralgia. J Am Med Assoc 1959;170(15):1773-1776

8 Gardner WJ. Concerning the mechanism of trigeminal neuralgia and hemifacial spasm. J Neurosurg 1962;19:947-958

9 Rand RW. The Gardner neurovascular decompression operation for trigeminal neuralgia. Acta Neurochir (Wien) 1981;58(3-4):161-166

10 Jannetta PJ. Arterial compression of the trigeminal nerve at the pons in patients with trigeminal neuralgia. 1967. J Neurosurg 2007;107(01):216-219

11 Jannetta PJ. Letter: Tic douloureux and facial spasm. JAMA 1974; 228(13):1637-1638

12 Jannetta PJ. Microsurgical approach to the trigeminal nerve for tic douloureux. In: Krayenbühl H, Maspes PE, Sweet WH(eds). Pain Its Neurosurgical Management. Part I: Procedures on Primary Afferent Neurons. Basel: Karger; 1976, Vol 7180-200

13 Jannetta PJ. Observations on the etiology of trigeminal neuralgia, hemifacial spasm, acoustic nerve dysfunction and glossopharyngeal neuralgia. Definitive microsurgical treatment and results in 117 patients. Neurochirurgia (Stuttg) 1977;20(05):145-154

14 Barker FG II, Jannetta PJ, Bissonette DJ, Larkins MV, Jho HD. The long-term outcome of microvascular decompression for trigeminal neuralgia. N Engl J Med 1996;334(17):1077-1083

15 Broggi G, Ferroli P, Franzini A, Servello D, Dones I. Microvascular decompression for trigeminal neuralgia: comments on a series of 250 cases, including 10 patients with multiple sclerosis. J Neurol Neurosurg Psychiatry 2000;68(01):59-64
16 Sindou M, Howeidy T, Acevedo G. Anatomical observations during microvascular decompression for idiopathic trigeminal neuralgia (with correlations between topography of pain and site of the neurovascular conflict). Prospective study in a series of 579 patients. Acta Neurochir (Wien) 2002;144(01):1-12, discussion $12-13$

17 van Loveren H, Tew JM Jr, Keller JT, Nurre MA. a 10-year experience in the treatment of trigeminal neuralgia. Comparison of percutaneous stereotaxic rhizotomy and posterior fossa exploration. J Neurosurg 1982;57(06):757-764

18 Piatt JH Jr, Wilkins RH. Treatment of tic douloureux and hemifacial spasm by posterior fossa exploration: therapeutic implications of various neurovascular relationships. Neurosurgery 1984; 14(04):462-471

19 Zorman G, Wilson CB. Outcome following microsurgical vascular decompression or partial sensory rhizotomy in 125 cases of trigeminal neuralgia. Neurology 1984;34(10):1362-1365

20 Bederson JB, Wilson CB. Evaluation of microvascular decompression and partial sensory rhizotomy in 252 cases of trigeminal neuralgia. J Neurosurg 1989;71(03):359-367

21 Klun B. Microvascular decompression and partial sensory rhizotomy in the treatment of trigeminal neuralgia: personal experience with 220 patients. Neurosurgery 1992;30(01):49-52

22 Baechli H, Gratzl O. Microvascular decompression in trigeminal neuralgia with no vascular compression. Eur Surg Res 2007;39 (01):51-57

23 Leal PRL, Hermier M, Froment JC, Souza MA, Cristino-Filho G, Sindou M. Preoperative demonstration of the neurovascular compression characteristics with special emphasis on the degree of compression, using high-resolution magnetic resonance imaging: a prospective study, with comparison to surgical findings, in 100 consecutive patients who underwent microvascular decompression for trigeminal neuralgia. Acta Neurochir (Wien) 2010;152(05):817-825

24 Revuelta-Gutierrez R, Martinez-Anda JJ, Coll JB, Campos-Romo A, Perez-Peña N. Efficacy and safety of root compression of trigeminal nerve for trigeminal neuralgia without evidence of vascular compression. World Neurosurg 2013;80(3-4):385-389

25 Ko AL, Ozpinar A, Lee A, Raslan AM, McCartney S, Burchiel KJ. Long-term efficacy and safety of internal neurolysis for trigeminal neuralgia without neurovascular compression. J Neurosurg 2015; 122(05):1048-1057

26 Hitchon PW, Bathla G, Moritani T, Holland MT, Noeller J, Nourski KV. Predictability of vascular conflict by MRI in trigeminal neuralgia. Clin Neurol Neurosurg 2019;182:171-176

27 Yang DB, Wang ZM. The efficacy and safety of nerve combing for trigeminal neuralgia without neurovascular compression. Acta Neurol Belg 2019;119(03):439-444. Doi: 10.1007/s13760-01901099-2

28 Ma Z, Li M. "Nerve combing" for trigeminal neuralgia without vascular compression: report of 10 cases. Clin J Pain 2009;25(01): 44-47

29 Jie H, Xuanchen Z, Deheng L, et al. The long-term outcome of nerve combing for trigeminal neuralgia. Acta Neurochir (Wien) 2013; 155(09):1703-1708, discussion 1707

30 Devor M, Amir R, Rappaport ZH. Pathophysiology of trigeminal neuralgia: the ignition hypothesis. Clin J Pain 2002;18(01):4-13

31 Rappaport ZH, Devor M. Trigeminal neuralgia: the role of selfsustaining discharge in the trigeminal ganglion. Pain 1994;56 (02):127-138

32 Peker S, Kurtkaya O, Uzün I, Pamir MN. Microanatomy of the central myelin-peripheral myelin transition zone of the trigeminal nerve. Neurosurgery 2006;59(02):354-359, discussion 354-359

33 Rappaport ZH, Govrin-Lippmann R, Devor M. An electron-microscopic analysis of biopsy samples of the trigeminal root taken during microvascular decompressive surgery. Stereotact Funct Neurosurg 1997;68(1-4 Pt 1):182-186 
34 McLaughlin MR, Jannetta PJ, Clyde BL, Subach BR, Comey CH, Resnick DK. Microvascular decompression of cranial nerves: lessons learned after 4400 operations. J Neurosurg 1999;90(01):1-8

35 Lee A, McCartney S, Burbidge C, Raslan AM, Burchiel KJ. Trigeminal neuralgia occurs and recurs in the absence of neurovascular compression. J Neurosurg 2014;120(05):1048-1054

36 Miller JP, Acar F, Hamilton BE, Burchiel KJ. Radiographic evaluation of trigeminal neurovascular compression in patients with and without trigeminal neuralgia. J Neurosurg 2009;110(04):627-632

37 Sindou M, Leston J, Decullier E, Chapuis F. Microvascular decompression for primary trigeminal neuralgia: long-term effectiveness and prognostic factors in a series of 362 consecutive patients with clear-cut neurovascular conflicts who underwent pure decompression. J Neurosurg 2007;107(06):1144-1153

38 Maarbjerg S, Wolfram F, Gozalov A, Olesen J, Bendtsen L. Significance of neurovascular contact in classical trigeminal neuralgia. Brain 2015;138(Pt 2):311-319

39 Hughes MA, Jani RH, Fakhran S, et al. Significance of degree of neurovascular compression in surgery for trigeminal neuralgia. J Neurosurg 2019;14:1-6

40 Brînzeu A, Drogba L, Sindou M. Reliability of MRI for predicting characteristics of neurovascular conflicts in trigeminal neuralgia: implications for surgical decision making. J Neurosurg 2018;130 (02):1-11

41 Rutland JW, Huang KH, Gill CM, et al. First application of 7-T ultrahigh field diffusion tensor imaging to detect altered microstructure of thalamic-somatosensory anatomy in trigeminal neuralgia. J Neurosurg 2019:1-9. Doi: 10.3171/2019.6.JNS19541

42 Taarnhøj P. Decompression of the trigeminal root and the posterior part of the ganglion as treatment in trigeminal neuralgia; preliminary communication. J Neurosurg 1952;9(03):288-290

43 Taarnhøj P. Decompression of the trigeminal root. J Neurosurg 1954;11(03):299-305

44 Shelden $\mathrm{CH}$, Pudenz RH, Freshwater DB, Crue BL. Compression rather than decompression for trigeminal neuralgia. J Neurosurg 1955;12(02):123-126

45 Adams CB, Kaye AH, Teddy PJ. The treatment of trigeminal neuralgia by posterior fossa microsurgery. J Neurol Neurosurg Psychiatry 1982;45(11):1020-1026

46 Young JN, Wilkins RH. Partial sensory trigeminal rhizotomy at the pons for trigeminal neuralgia. J Neurosurg 1993;79(05):680-687

47 Zakrzewska JM, Lopez BC, Kim SE, Coakham HB. Patient reports of satisfaction after microvascular decompression and partial sensory rhizotomy for trigeminal neuralgia. Neurosurgery 2005;56 (06):1304-1311, discussion 1311-1312

48 Terrier L-M, Amelot A, François P, Destrieux C, Zemmoura I, Velut $S$. Therapeutic failure in trigeminal neuralgia: from a clarification of trigeminal nerve somatotopy to a targeted partial sensory rhizotomy. World Neurosurg 2018;117:e138-e145

49 Ishikawa M, Nishi S, Aoki T, et al. Operative findings in cases of trigeminal neuralgia without vascular compression: proposal of a different mechanism. J Clin Neurosci 2002;9(02):200-204

50 Revuelta-Gutiérrez R, López-González MA, Soto-Hernández JL. Surgical treatment of trigeminal neuralgia without vascular compression: 20 years of experience. Surg Neurol 2006;66(01): 32-36, discussion 36

51 Cheng J, Lei D, Zhang H, Mao K. Trigeminal root compression for trigeminal neuralgia in patients with no vascular compression. Acta Neurochir (Wien) 2015;157(02):323-327
52 Urculo E, Elua A, Arrazola M, Torres P, Torres S, Undabeitia J. Trigeminal root massage in microsurgical treatment of trigeminal neuralgia patients without arterial compression: When, how and why. Neurocirugia (Astur) 2020;31(02):53-63

53 Li M, Yu GZ, Guan Y, et al. Nerve combing treat for trigeminal neuralgia. Zhonghua Er Bi Yan Hou Za Zhi (China) 1995;30:377

54 Ashkan K, Marsh H. Microvascular decompression for trigeminal neuralgia in the elderly: a review of the safety and efficacy. Neurosurgery 2004;55(04):840-848, discussion 848-850

55 Zhao H, Zhang X, Tang D, Li S. Nerve combing for trigeminal neuralgia without vascular compression. J Craniofac Surg 2017;28 (01):e15-e16

56 Kline D, Hudson A. Acute injuries of peripheral nerve. In: JR Y(ed). Neurological surgery. WB Saunders: Philadelpia; 1996:2103-2181

57 Zhou X, Liu Y, Yue Z, Luan D, Zhang H, Han J. Comparison of nerve combing and percutaneous radiofrequency thermocoagulation in the treatment for idiopathic trigeminal neuralgia. Rev Bras Otorrinolaringol (Engl Ed) 2016;82(05):574-579

58 Pollock BE, Stien KJ. Posterior fossa exploration for trigeminal neuralgia patients older than 70 years of age. Neurosurgery 2011; 69(06):1255-1259, discussion 1259-1260

59 Zhang H, Lei D, You C, Mao BY, Wu B, Fang Y. The long-term outcome predictors of pure microvascular decompression for primary trigeminal neuralgia. World Neurosurg 2013;79(56):756-762

60 Wei Y, Pu C, Li N, Cai Y, Shang H, Zhao W. Long-Term Therapeutic Effect of Microvascular Decompression for Trigeminal Neuralgia: Kaplan-Meier Analysis in a Consecutive Series of 425 Patients. Turk Neurosurg 2018;28(01):88-93

61 Zhang X, Xu L, Zhao H, et al. Long-Term Efficacy of Nerve Combing for Patients with Trigeminal Neuralgia and Failed Prior Microvascular Decompression. World Neurosurg 2017;108:711-715

62 Liang X, Dong X, Zhao S, Ying X, Du Y, Yu W. A retrospective study of neurocombing for the treatment of trigeminal neuralgia without neurovascular compression. Ir J Med Sci 2017;186(04): 1033-1039. Doi: 10.1007/s11845-016-1547-y

63 Wu M, Jiang X, Niu C, Fu X. Outcome of internal neurolysis for trigeminal neuralgia without neurovascular compression and its relationship with intraoperative trigeminocardiac reflex. Stereotact Funct Neurosurg 2018;96(05):305-310. Doi: 10.1159/000493547

64 Ko AL, Lee A, Raslan AM, Ozpinar A, McCartney S, Burchiel KJ. Trigeminal neuralgia without neurovascular compression presents earlier than trigeminal neuralgia with neurovascular compression. J Neurosurg 2015;123(06):1519-1527

65 Magown P, Ko AL, Burchiel KJ. The spectrum of trigeminal neuralgia without neurovascular compression. Neurosurgery 2019;85(03):E553-E559

66 Rath SA, Klein HJ, Richter H-P. Findings and long-term results of subsequent operations after failed microvascular decompression for trigeminal neuralgia. Neurosurgery 1996;39(05):933-938, discussion 938-940

67 Bakker NA, Van Dijk JM, Immenga S, Wagemakers M, Metzemaekers JD. Repeat microvascular decompression for recurrent idiopathic trigeminal neuralgia. J Neurosurg 2014;121(04):936-939

68 Guo H, Song G, Wang X, Bao Y. Surgical treatment of trigeminal neuralgia with no neurovascular compression: A retrospective study and literature review. J Clin Neurosci 2018;58:42-48. Doi: 10.1016/j.jocn.2018.10.066 